\title{
Studi Perbandingan Struktur Selulosa Dengan Pretreatment Larutan Ion Pada Kayu Cempaka (Elmerillia Ovalis)
}

\author{
Muhamad Rifai Sehea, Hanny F. Sangiana*, Seni H.J. Tongkukuta* \\ aJurusan Fisika, FMIPA, Unsrat, Manado
}

KATA KUNCI

Pretreatment, morfoogi, selulosa, XRD, FTIR, SEM

\begin{abstract}
A B S TR A K
Penelitian ini bertujuan untuk menentukan struktur selulosa dari serbuk kayu cempakasebelum dan sesudah pretreatment menggunakan SEM, XRD, dan FTIR. Serbuk kayu cempaka ditreatment menggunakan larutan ion dengan konsentrasi 10\%, 20\%, dan 27\% garam. Hasilnya menunjukan bahwa secara X-ray Diffraction ukuran partikel terkecil terjadi pada treatment dengan konsentrasi $27 \%$ garam yaitu $2,8 \mathrm{~nm}$. Secara spktrum inframerah terjadi perubahan yang signifikan yang ditunjukan pada gugus fungsi O-H streaching dengan bilangan gelombang $3317,56 \mathrm{~cm}^{-1}$. Selanjutnya ukuran pori terkecil terjadi pada konsentrasi yang sama dan tergolong sebagai membran konvonsional filtrasi.
\end{abstract}

\section{KEYWOR D S}

Pretreatment, morphoogy, cellulose, XRD, FTIR, SEM

\begin{abstract}
A B S T R A C T
This study aims to determine the cellulosic structure of wood powder before and after pretreatment using SEM, XRD, and FTIR. Chestnut wood powder is treated using ion solution with concentration of $10 \%, 20 \%$, and $27 \%$ salt. The results showed that X-ray Diffraction of the smallest particle size occurred in treatment with $27 \%$ salt concentration whose the size was of $2.8 \mathrm{~nm}$. In infrared spktrum there was a significant change shown in the

$\mathrm{O}-\mathrm{H}$ streaching function group with wave number $3317.56 \mathrm{~cm}^{-1}$. Furthermore, the smallest pore size occurred at the same concentration the highest precentegc of salt and is classified as conventional filtration membrane.
\end{abstract}

TERSEDIA ONLINE

1 Februari 2018

\section{Pendahuluan}

Tumbuh-tumbuhan yang mengandung selulosa cukup melimpah dilndonesia dan merupakan sumber alam yang sangat potensial untuk dikembangkan sebagai energit terbarukan. Material yang dapat diperbaharui misalnya kayu, kulit kayu, dan biomassa lainnya (Galbe dan Zachli, 2007 ; Sangian $d k k, 2015)$

Senyawa organik dari semua materi tanaman yang terdapat di bumi sekitar 33\% adalah selulosa, pada tanaman kapas ditemukan selulosa $90 \%$ dan kayu ( $40-50 \%)$. Selulosa merupakan komponen struktural utama dinding sel dari tanaman hijau, yang berbentuk ganggang dan Oomycetes, beberapa spesies mengeluarkan bakteri untuk membentuk biofilm (Nadia et al,2012).
Jumlah selulosa dalam serat bervariasi menurut sumbernya dan biasanya berkaitan dengan bahanbahan seperti air, lilin, pektin, protein, lignin dan substansi-substansi mineral. Derajat polimerisasi dari selulosa kapas berkisar 15.\% dibandingkan dengan kayu sekitar 10.\%. Pemisahan selulosa kayu dari lignin menyebabkan penurunan derajat polimerisasi menjadi $26 \%$.

Pretreatment telah dilakukan ke beberapa bahan lignoselulosa, salah satunya karakterisasi dari tandan kosong kelapa sawit dengan pretreatmen hidrolisis asam dan dikarakterisasi menggunakan SEM, DTA, FTIR, dan TGA. Pada FTIR terdapat serapan $3348,42-3441,01 \mathrm{~cm}^{-1}$, yang menunjukan adanya gugus $\mathrm{OH}$ (Nosya,2015). Sangian, widjaja dan Fathoni,(2015) mengatakan bahwa modifikasi selulosa dengan senyawa organik dapat dilakukan dengan menggunakan metode penempelan dan impregnasi. Selulosa termodifikasi

*Corresponding author: Jurusan Fisika FMIPA UNSRAT, Jl. Kampus Unsrat, Manado, Indonesia 95115; Email address: hannysangian@yahoo.com Published by FMIPA UNSRAT (2017) 
kemudian digunakan sebagai adsorben ion $\mathrm{Cu}(\mathrm{II})$ dalam larutan berair. Tujuan dari penelitian ini adalah memodifikasi struktur selulosa dari 3kloropropiltrimetoksisilen dan 2merkaptobenzotiazol (MBT), kemudian dikarakterisasi menggunakan FTIR, SEM, dan XRD. Dalam Penelitian Ahmed et al. (2015) menyatakan bahwa selulosa teraktivasi dapat dimodifikasi dengan senyawa organik menjadi adsorben selulosa-MBT dengan ion $\mathrm{Cu}$ (II) dalam larutan berair. Bahan lignusselulosa berhasil dimodifikasi dengan menggunakan gelombang elektromagnetik, seperti ultraviolet (UV) dan dapat meningkatkan sifat kekuatan serat selulosa (Mikaela, 2013 ; pangau, 2017 ; sasue 2017)

Penelitian ini, lignoselulosa yang digunakan diperoleh dari serbuk kayu cempaka, karna sangat mudah ditemui di Indonesia khususnya di Sulawesi utara. Terdapat 6 (enam) jenis kayu cempaka di Sulawesi Utara yang berasal dari 3 genus yaitu Elmerrillia, Magnolia, dan Michelia. Jenis-jenis kayu cempaka tersebut adalah Elmerrillia celebica, Elmerrilia ovalis, Elmerrillia tsiampacca, Magnolia elegans, Magnolia candollei, dan Michelia champaca (Kinho dan Irawan, 2016).

Penelitian ini menggunakan bahan baku kayu cempaka (Elmerilia Ovalis) yang diperoleh dari limba industri rumah panggung Minahasa (Kinho dan Mahfudz, 2011).

Studi ini bertujuan untuk membandingkan struktur lignoselulosa denganpretreatment larutan ion dan nonpretreatment

\section{Material dan Metode \\ Alat dan Bahan yang Digunakan}

Bahan-bahan yang digunakan adalah serbuk kayu cempaka, plastik sampel,beker gelas 800 $\mathrm{ml}$,serbet, sendok pengaduk, saringan 120 mesh, buku tabel. Kemudian alat-alat yang digunakan yaitu timbangan dan penggiling kayu mesin somel wood crusher.

\section{Preparasi Kayu Cempaka}

Potongan kayu cempaka diperoleh dari limbah pengergajian kayu di Desa Tombatu Satu, Jaga II, Kecamatan Tombatu, Kabupaten Minahasa Tenggara, Provinsi Sulawesi Utara. Sampel kayu cempaka dikeringkan dibawah sinar matahari, selanjutnya digiling menggunakan mesin somel wood crusher dan dihaluskan dengan ayakan berukuran 120 mesh, sehingga diperoleh serbuk kayu cempaka.

\section{Pretreatment Larutan Ion}

Sebanyak 100 gram serbuk kayu cempaka dimasukan kedalam beker gelas $1000 \mathrm{ml}$, ditambahkan larutan garam dengan konsentrasi terrendah, medium, dan tertinggi kemudian didiamkan selama 14 hari, selanjutnya disaring mengunakan sarbet sehingga diperoleh filtrat dan endapan. Diambil endapannya, kemudian dicuci dengan air dan dikeringkan.

Karakterisasi Struktur dengan X-RD, SEM dan FT-IR
Setelah dilakukan pretreatment sampel akan dikarakterisasi menggunakan SEM, XRD, dan FTIR. (Groeberet al., 2006)

\section{Scanning Electron Microscope SEM}

Bertujuan untuk mengetahui informasi informasi mengenai: Topografi, Morfologi, Komposisi, dan Informasi Kristalografi dari suatu partikel. (Hotovyet al., 2004)

\section{$X$-ray Diffraction XRD}

X-ray Diffraction XRD dapat digunakan untuk menentukan struktur kristal menggunakan sinar $\mathrm{X}$, metode ini digunakan untuk menggidentifikasi jenis struktur, ukuran butir, konstanta kisi, dan FWHM.

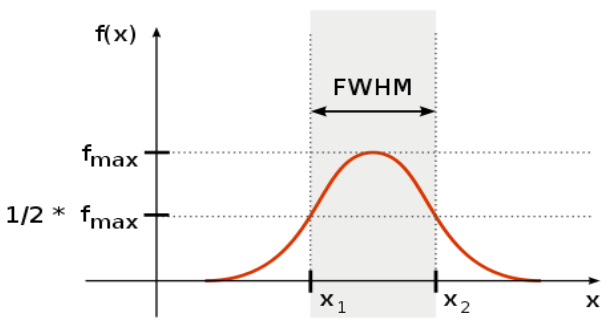

Gambar 1. Difaktogram FWHM

Fourier-Transform Infrared Spectroscopy (FTIR) atau spektoskopi infra merah merupakan suatu metode yang mengamati interaksi molekul dengan radiasi elektromagnetik yang berada pada daerah panjang gelombang 0,75 - $1.000 \mu \mathrm{m}$ atau pada Bilangan Gelombang $13.000-10 \mathrm{~cm}-1$.

\section{Hasil dan Pembahasan \\ Karakterisasi Kayu Cempaka Menggunakan XRD (X- Ray Diffraction)}

Berdasarkan pola XRD pada Gambar 4, terlihat bahwa sampel serbuk kayu cempaka sebelum dan sesudah perlakuan larutan ion memiliki pola yang sama, dengan komponen-komponen berbentuk amorf dan kristal (Steveet al,. 2013). Bentuk amorf ditunjukan pada sampel yang sebelum di pretreatment dan sesudah preteratment larutan ion dengan konsentrasi terrendah, medium dan tertinggi mengalami perubahan namun tidak begitu singnifikan. Hasil penelitian sejalan dengan Han-Yin et al., (2016) yang mengatakan yang mengatakan bahwa setelah pretreatment larutan ion, dinding sel menjadi longgar dan bahkan membengkak, disertai dengan penurunan kristalinitas selulosa dan pengangkatan hemiselulosa dan juga lignin yang tidak begitu signifikan.

Grafik yang ditampilkan pada Gambar 4 menunjukan puncak-puncak dalam spektrum XRD dari suatu intensitas dengan sudut pada berbagai konsentrasi. Diperoleh hasil puncak yang teridentifikasi dalam spektrum XRD sebanyak pada Tabel 2 berikut:

Tabel 2. menunjukkan bahwa terjadi perubahan intensitas antara sampel sebelum dan sesudah dilakukan treatmentlarutan ion dari berbagai 
konsentrasi. Perubahan intensitas terjadi karena pengaruh konsentrasi larutan garam yang besa pada treatment/perlakuan. Data yang dihasilkan tersebut, pada $\quad$ Gambar 4 menunjukanpretreatmentlarutan ion dengan konsentrasi garam 27\%, berkemampuan untuk menyerap cahayadengan intensitas yang lebih rendah. Semakin tinggi konsentrasi larutan garam, semakin rendah penyerapan foton/cahaya sehingga terjadi penurunan intensitas serapan. Hal ini sejalan dengan penelitian yang dilakukan oleh (Umesh $p$ et al., 2017: Sangian, widjaja., 2015).

Difaktogram X-ray Diffraction material kayu cempaka pada Gambar 4 juga memberikan informasi mengenai (Full width at half maximum) FWHM dan ukuran partikel, seperti pada tabel 3.

Tabel 3 juga menunjukkan intensitas difraksi semakin berkurang dan (Full width at half maximum) FWHM (lebar puncak difraksi) semakin meningkat dengan adanya peningkatan konsentrasi ionik liquid (garam). Ukuran partikel terkecil terjadi pada treatment/perlakuan larutan iondengan konsentrasi garam 27\%. Kristal yang berukuran besar dengan satu orientasi menghasilkan puncak difraksi yang mendekati sebuah garis vertikal. Kristal yang sangat kecil menghasilkan puncak difraksi yang sangat lebar (Zhang et al., 2010).

\section{Karakterisasi Kayu Cempaka menggunakan Fourier Transform Infra Red (FTIR)}

Berdasarkan pada Gambar 5, terlihat bahwa puncak serapan dari spketrum inframerah memiliki perbedaan yang signifikan pada perlakuan larutan ion dengan beberapa konsentrasi larutan garam. Selulosa dari serbuk kayu cempaka perlakuan dan tanpa perlakuan larutan garam ditunjukkan dengan serapan gugus $\mathrm{O}-\mathrm{H}$ streaching vibrasi, gugus $\mathrm{C}-\mathrm{H}$ streaching vibrasi, gugus $\mathrm{C}-\mathrm{O}$ bending vibrasi (Ndanaet al., 2013). Dan juga gugus fungsi C-O glikosida bending vibrasi (Pillaiet al., 2014). Gugus $\mathrm{O}-\mathrm{H}, \mathrm{C}-\mathrm{H}, \mathrm{C}-\mathrm{O}$, dan $\mathrm{C}-\mathrm{O}$ glikosidik merupakan gugus utama selulosa. Analisis karakterisasi spektral dari gugus fungsi pada serbuk kayu cempaka dengan berbagai konsentrasi larutan garam dapat dilihat pada Tabel 4.

Berdasarkan Tabel 4, dapat diketahui bahwa semakin tinggi konsentrasi garam, bilangan gelombang yang semakin menurun ditunjukkan oleh perubahan gugus fungsi yaitu penghilangan salah satu unsur hidrogen dari gugus HO-selulosa dan digantikan oleh ion natrium dari $\mathrm{NaCl}$ sehingga menghasilkan produk suatu senyawa natrium selulosa. Hal ini sejalan dengan Thayihiyah, (2009) yang menyatakan bahwa perubahan gugus fungsi selulosa dari eceng gondok dengan perlakuan anhidrat asetat membentuk reaksi asetilasi sehingga menunjukkan gugus asetil dapat berikatan dengan selulosa menjadi selulosa asetat

Karakterisasi Kayu Cempaka (Elmerrilia Ovalis) Menggunakan (Scanning Electron Microscope) SEM

Berdasarkan citra SEM untuk material serbuk kayu cempaka sebelum dan sesudah pretreatment larutan garam dengan berbagai konsentrasi, karakterisasi SEM menunjukkan terjadinya perubahan morfologi permukaan sehingga menghasilkan pengurangan komponen - komponen biomolekuler. Hal itu terjadi saat treatment/perlakuan larutan ion dengan konsentrasi medium dan tertinggi garam.Pada konsentrasi ini ukuran porinya tampak mengecil dan relatif tidak terlihat sehingga dapat digolongkan sebagai kategori membran konvensonal filtrasi karena memiliki ukuran pori sekitar $10 \mu m-100 \mu m$. Menurut Setiawan et al. (2015) semakin tinggi tingkat konsentrasi garam maka semakin padat tingkat kerapatan partikelnya yang mengakibatkan ukuran pori membran menjadi kecil.

\section{Kesimpulan}

Pretreatment menggunakan larutan ion (larutan garam) dapat merubah sifat dan fisik selulosa pada serbuk kayu cempaka. Hal ini diketahui karena:

$>$ Secara spektrum inframerah terjadi perubahan yang singnifikan, pada saat perlakuan larutan ion dengan konsentrasi 27\% garam, dibandingkan dengan konsentrasi 10\%, $20 \%$, dan tanpa perlakuan

$>$ Hal ini diperkuat dengan adanya karakterisasi Xray Diffraction yang memperliihatkan ukuran terkecil kristal terjadi pada konsentrasi yang sama, begitu juga dengan ukuran pori pada morfologi permukaan. Semakin tinggi konsentrasi garam maka semakin besar perubahan yang terjadi pada serbuk kayu cepaka.

\section{Daftar Pustaka}

Ahmad, Soerja, Nurlisa. 2015. Synthesis, Characterization of Cellulose Modified With 2Mercaptobenzothiazole And Its Adsorption To $\mathrm{Cu}$ (li) Ion In Aqueous Solution. Indones. J. Chem. 15(2):194-200

Groeber M.A., Haley B.K., Uchic M.D., Diminduk D.M., dan Ghosh S., 2006. 3D Reconstruction and Characterization of Polycrystalline Microstructures Using a FIB-SEM System. Materials Characterization. 259-273.

Han-Yin, li., Xue Chen, Chen-Zhou Wang, Shao-Ni Sun, Run-Cang Sun. 2016. Evaluation of the two-step treatment with ionic liquids and alkali for enhancing enzymatic hydrolysis of Eucalyptus: chemical and anatomical changes. Biotechnology for biofuels. 9: 166

Hotovy I., Huran J., dan Spiess L., 2004. Characterization of Spttered Mio Films Using XRD and AFM. Journal Of Materials Science. 4(39)-2609-2612.

Julianus Kinho dan Mahfudz. 2011. Prospek Pengembangan Cempaka Di Sulawesi Utara. Badan Penelitian Dan Pengembangan 
Kehutanan Balai Penelitian Kehutanan Manado. 1-29

Kinho J., dan Irawan A., 2016. Studi Keragaman Jenis Cempaka Berdasarkan Karakterisasi Morfologi di Sulawesi Utara. Conference Paper.

Nadia, Mohamad, Amin, Ishak. 2012. Physicochemical Properties and Characterization of Nata de Coco from Local Food Industries as a Source of Cellulose. Sains Malaysiana.41(2):205-211

sangian, H.F., J. Kristian, S.Rahman, S.Y. Agnesty, S.Gunawan dan A. Winjaja. 2015. Comparative study of the preparation of reducing sugars hydrolyzed from hing-lignin lignocellulose pretreated with ionic liquid, alkaline solution and their combination. J. Eng. Tecnhol. Sce. 47.(2):137-148.

Setiawan, D.A., Argo, B.D., Hendrawan, Y. 2015. Engaruh Konsentrasi dan Preparasi Membran Terhadap Karakterisasi Membran Kitosan. Jurnal Keteknikan Pertanian Tropis dan Biosistem. 3:(1) : 95-99.

Steve, J., Chipera, David. L., Bish. 2013. Fitting Full X-Ray Diffraction Patterns for Quantitative Analysis: A Method for Readily Quantifying Crystalline and Disordered Phases. AdvancesinMaterialsPhysicsandChemistry. $3: 47-53$
Zhang $\mathrm{T}$, Wang $\mathrm{W}$, Zhang $\mathrm{D}$, Zhang $\mathrm{X}$, Yurong $\mathrm{M}$. 2010. Biotemplated synthesis of gold nanoparticle-bacteria cellulose nanofiber nanocomposites and their application in biosensing. J Advanced Functional Materials20: 1152-1160.

Pangau J.R., Sangian H.F, Lumi B.M. 2017. Arakterisasi Bahan Selulosa Dengan Iradiasi Dengan Pretreatment Gelombang Mikro Terhadap Serbu Kayu Cempaa Wasian (Elmerillia Ovalis) Di Sulawesi Utara. Jurnal Mipa Unsrat Online. 6(1)

Sasue R, Sangian H.F., Mosey I.R. 2017. Analisis Pengaruh Radiasi Gelombang Mikro Pada Strutur Kristal Pati (Starch). Jurnal Mipa Unsrat Online. 6(1)

Sangian H.F, Widjaja A. 2017. Effek Of Pretreatment Method On Structrural Cangees Of Coconut Cair Dust. Bio Resource. 12(4)

Sangian H.F, Kristian J, Rahma S, Yusnia S, Gunawan S, Midjaja A. 2015. Comparative Study Of The Preparation Of Reduing Sugars Hydrolyzet From Higt-Lingnin Lignoelluse Pretreated With Ionic Liquid, Alkaline Solution And Their Combination. Journal Of Enginereering And Tenologial Scienes. 47(2) 